\title{
Degasification of methane for high methane-emitted coal seam at Mao Khe coal mine - Vinacomin by drilling long borehole
}

\author{
Duy Van Pham ${ }^{1}$, Dung Tien Le ${ }^{2,}$, Son Anh Do ${ }^{2}$ \\ 1 Mao Khe Coal Company - Vinacomin, Quang Ninh, Vietnam \\ ${ }^{2}$ Hanoi University of Mining and Geology, Hanoi, Vietnam
}

\section{ARTICLE INFO}

Article history:

Received 29th July 2021

Revised 02 $2^{\text {nd }}$ Nov. 2021

Accepted 30 $0^{\text {th }}$ Nov. 2021

\section{Keywords:}

Borehole,

Gas combustion,

Gas explosion,

Gasification,

Methane.

\section{ABSTRACT}

This paper presents a technical solution for reducing methane gas concentration (degasification) caused by a high methane-emitted coal seam at Mao Khe coal mine - Vinacomin. The technique is implemented by drilling a long borehole from the footwall of the roadway into the coal seam and punching small holes along the borehole for gas release. A field study at the longwall level -150/-80 m at Seam 9 of Mao Khe coal mine shows that after the degasification, the gas concentration here is lowered to safety standards. The technique can be used for all coal seams ranked as Class II, Class III, and super-class regarding methane gas, minimizing the risk of methane combustion and explosion.

Copyright (C) 2021 Hanoi University of Mining and Geology. All rights reserved.

\section{Introduction}

Methane gas is formed along with the formation of coal. It can exist as free gas, stored in porosity, or absorbed in coal seams that may cause dangerous combustion and explosion incidents (Tran et al., 2019). The combustion and explosion of methane gas during underground coal mining has been recognized as a top priority problem in Vietnam and globally because it has resulted in many fatalities and severe damage to equipment. To effectively prevent the risk of

${ }^{*}$ Corresponding author

E-mail: t.d.le@humg.edu.vn

DOI: 10.46326/JMES.2021.62(6).08 methane combustion and explosion, it is essential to understand the characteristics of this gas.

Methane is colorless, odorless and tasteless that can not be felt by humans. The gas concentration resulting in explosions is found by methane gas measurement devices in the range of $5-15 \%$. The gas concentration resulting in the terrible explosion is $9.5 \%$, with a firing temperature of $650-750^{\circ} \mathrm{C}$ (Kundu et al., 2016). Three factors contributing to gas combustion or explosion are oxygen, methane,, and fire source. If a gas concentration reaches a critical limitation, an explosion occurs.

A methane gas explosion releases a super high temperature and a tremendous amount of energy that cause severe damage to human beings 
and equipment. The temperature of gas explosion can reach $1,850^{\circ} \mathrm{C}$ in a roadway or $2,650^{\circ} \mathrm{C}$ in a closed environment (Vinacomin, 2016). The explosion destroys mining equipment, roadways, faces, and other underground excavations.

Some catastrophic incidents of methane explosion and combustion in Quang Ninh coalfield are listed as follows. On 11 th Jan. 1999, the methane explosion occurred at Mao Khe coal mine, Seam 9 roadway, Crosscut 1, level -25 m that caused 19 fatalities and 06 injured (Figure 1) (Vietnam Ministry of Industry, 1999). On 19th Dec. 2002, the Suoi Lai coal mine explosion caused 13 casualties (VnExpress, 2002). On 6 ${ }^{\text {th }}$ Mar. 2006, the explosion occurred at Thong Nhat coal mine and caused 08 human loss (VnExpress, 2006). Two years later, on $8^{\text {th }}$ Dec. 2008, the incident happened in Khe Cham coal mine with 08 fatalities (Vietnam Government Portal, 2008). An example of gas combustion is seen at Dong Vong coal mine on $15^{\text {th }}$ Jan. 2014 (Figure 2) (Thanhnien, 2014).

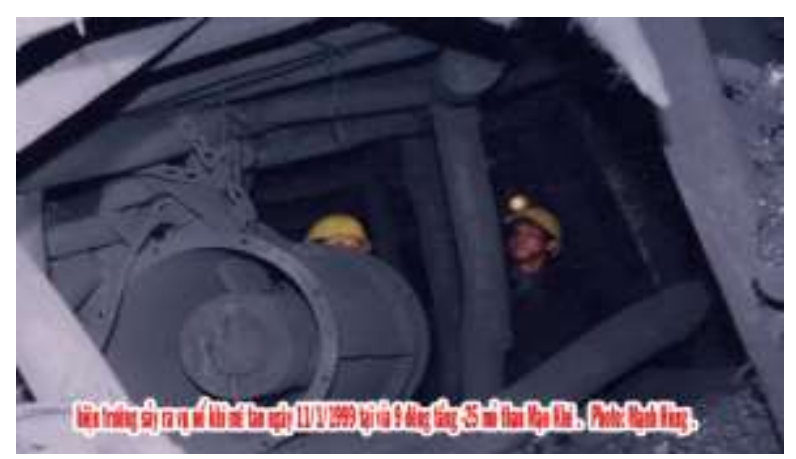

Figure 1. Methane explosion at Mao Khe coal mine in 1999.

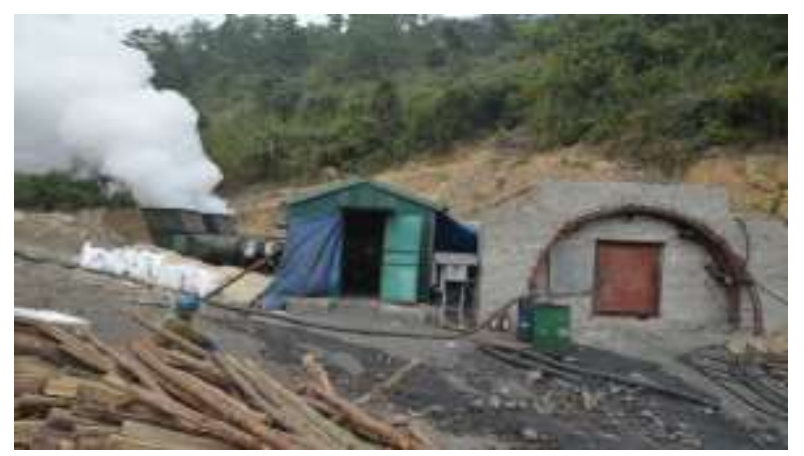

Figure 2. Methane combustion at Dam Vong coal mine in 2014.
It was soon recognized from practice that a methane combustion/explosion cannot be prevented by reducing the oxygen concentration in roadway or face air. It is because on-site workers need a certain amount of fresh air for respiration. The proper approach is to reduce the methane concentration and eliminate any sources that can trigger combustion in underground excavations. A technique for reducing methane gas concentration (degasification) by drilling a long borehole is proposed and tested at Mao Khe coal mine. This mine has been ranked as superclass according to methane gas (Vietnam Ministry of Industry and Trade, 2011-2020). Detailed site information, technique implementation, and monitoring results are presented in the next sections.

\section{Site of study}

The study was implemented in roadway level -150 m of longwall level -150/-80 m, Seam 9, Mao Khe coal mine. After the methane explosion in 1999, Mao Khe coal mine has implemented various measures to control gas concentration, especially methane. The collection of gas and coal samples to determine coal seam methane emission has been done by the Centre of Mining Safety - Vinacomin, based on Vietnam Ministry of Industry and Trade (2011). Through the years, the company has had Seam 9 East, Seam 6 East, Seam 9 TBII, and Seam 10 TBII ranked as superclass according to methane emission. In 2021, Seam 9 TBII is ranked as super-class according to the Vietnam Ministry of Industry and Trade (2021), as shown in Table 1.

At present, the company has operated the mining at Seam 9 TBII level -150/-80. This panel is ranked as super-class according to methane gas, based on the site measurement. According to the analysis of Center of Mining Safety - Vinacomin on 10th Jun. 2020 at Roadway -150 m East (Table 2), the gas concentration in seam roadway was in the range of $1.3-8 \%$ and often exceeded the critical value, which is $1.3 \%$ according to Vietnam Ministry of Industry and Trade (2011). It falls within the explosion range. Production shifts had to stop for ventilation and degasification. Thus, it 
Table 1. 2021 Rank of coal seams according to methane gas for Mao Khe coal mine (Vietnam Ministry of Industry and Trade, 2021).

\begin{tabular}{|c|c|c|c|c|c|}
\hline Mine & $\begin{array}{c}\text { Seam/Zone/Lo } \\
\text { ngwall }\end{array}$ & $\begin{array}{l}\text { Mining } \\
\text { level }\end{array}$ & $\begin{array}{c}\text { Relative gas emission } \\
\left(\mathrm{m}^{3} / \mathrm{T}_{\text {day-night }}\right)\end{array}$ & $\begin{array}{c}\text { Natural gas } \\
\text { content }\left(\mathrm{m}^{3} / \mathrm{T}_{\mathrm{KC}}\right) \\
\end{array}$ & $\begin{array}{c}\text { Rank in } \\
2021 \\
\end{array}$ \\
\hline \multirow{18}{*}{$\begin{array}{l}\text { Mao } \\
\text { Khe }\end{array}$} & Seam 1 CB & $-150 \div-76$ & 7,69 & 0,45194 & \multirow{18}{*}{$\begin{array}{l}* \text { Super- } \\
\text { class }\end{array}$} \\
\hline & Seam 5 West & $-150 \div-80$ & 9,81 & 0,88263 & \\
\hline & Seam 5 TBII & $-150 \div-80$ & 8.85 & 1,73352 & \\
\hline & Seam 6 East & $-150 \div-80$ & 7,76 & 0,19757 & \\
\hline & Seam 6 ĐMR & $-150 \div-80$ & 13,79 & 1,3709 & \\
\hline & Seam 7 TBIII & $-80 \div-25$ & 11,4 & 1,22154 & \\
\hline & Seam 8 ĐNI & $-150 \div-80$ & & 0,20141 & \\
\hline & Seam 8ĐNII & & 10,04 & & \\
\hline & Seam 8 TBII & $-150 \div-80$ & 17,45 & 1,04122 & \\
\hline & Seam 8 TBIII & $-80 \div-25$ & 7,73 & 0,99705 & \\
\hline & Seam 9A TNI & $-150 \div-80$ & 13,96 & & \\
\hline & Seam 9B West & $-150 \div-80$ & 7,04 & 0,31871 & \\
\hline & Seam 9B TBII & $-150 \div-80$ & & 0,1942 & \\
\hline & Seam 9 East & $-150 \div-80$ & 6,86 & 0,62238 & \\
\hline & Seam 9 TBII* & $-150 \div-80$ & 23,18 & 3,77889 & \\
\hline & Seam $10 \mathrm{CB}$ & $+152 \div+220$ & 6,55 & 1,32056 & \\
\hline & Seam 10 West & $-150 \div-80$ & 8,79 & 0,24498 & \\
\hline & Seam 10 TBII & $-150 \div-80$ & 16,89 & 1,34521 & \\
\hline
\end{tabular}

Table 2. Results of methane gas content and gas concentration in boreholes (Center of Mining Safety - Vinacomin, 2020).

\begin{tabular}{|c|c|c|c|c|c|c|c|c|}
\hline $\begin{array}{c}\text { Sampling } \\
\text { date }\end{array}$ & $\begin{array}{l}\text { Sampling } \\
\text { location }\end{array}$ & $\begin{array}{c}\text { Coal } \\
\text { sample } \\
\text { name }\end{array}$ & $\begin{array}{c}\text { Gas } \\
\text { content } \\
\left(\mathrm{m}^{3} / \mathrm{T}_{\mathrm{KC}}\right)\end{array}$ & $\begin{array}{c}\text { Gas } \\
\text { sample } \\
\text { name }\end{array}$ & \multicolumn{4}{|c|}{ Gas concentration in borehole (\%) } \\
\hline \multirow{4}{*}{$\begin{array}{c}10 \text { June } \\
2020\end{array}$} & \multirow{4}{*}{$\begin{array}{c}\text { Roadway }-150 \\
\text { Seam 9TBII } \\
\text { level -150/-80 }\end{array}$} & 69 & 1,042 & \multirow{4}{*}{ AT10 } & $\mathrm{O}_{2}$ & $\mathrm{~N}_{2}$ & $\mathrm{CO}_{2}$ & $\mathrm{CH}_{4}$ \\
\hline & & 005 & 1,356 & & \multirow{3}{*}{0,6854} & \multirow{3}{*}{6,8375} & \multirow{3}{*}{1,4609} & \multirow{3}{*}{90,8002} \\
\hline & & VD144 & 3,779 & & & & & \\
\hline & & NB02 & 2,785 & & & & & \\
\hline
\end{tabular}

takes more time for driving, maintaining and supporting roadway faces.

Consequently, the roadway was further damaged, which facilitated the emission of methane from the coal seam. The company implemented two solutions to resolve the problem. First, two local fans (with the power of 22-30 kW) combined with two air pipes (in diameter of $600 \mathrm{~mm}$ ) were installed and operated in parallel. Second, a $21 \mathrm{~mm}$-diameter zinc pipe was installed to eject air into the roadway face. The gas concentration reduced, which was $1.3 \div 5.5 \%$, but it still exceeded the critical value.
The risk of methane combustion and explosion remained very high at the site (Mao Khe Coal Company, 2020).

\section{Drilling technique and results}

Before the coal extraction and recovery at the horizontal-inclined longwall level $-150 /-80 \mathrm{~m}$ (extraction length of $202 \mathrm{~m}$ ), the degasification is implemented at the longwall's roadway by drilling a long borehole. The borehole is drilled from level $-150 \mathrm{~m}$ up to level $-128 \mathrm{~m}$ using exploration or dewatering drill (e.g., KD-150 or equivalent). In the first step, the location for 
drilling should be placed at the roadway' footwall at an interval of $10 \mathrm{~m}$ (Figure 3a). In the second step, the drilling is implemented in boreholes with a diameter of $76 \mathrm{~mm}$ for drill bit, $42 \mathrm{~mm}$ for the drill core, length of $20 \div 30 \mathrm{~m}$, and dip angle of $30 \div 35^{\circ} \mathrm{C}$ (Figure $3 \mathrm{~b}$ ). Note that after drilling, boreholes are refined to prevent collar collapse. In the last step, boreholes are supported by PVC plastic pipes with a diameter of $34 \mathrm{~mm}$, along which small holes of $3 \div 5 \mathrm{~mm}$ diameter are punched for gas release from the coal seam (Figure 3c). During the drilling for degasification, the gas concentration at the drilling location must be measured regularly to ensure safety.

After the drilling, gas concentration is measured using hand-held measurement devices (e.g., X-AM500, MX6) and an automatic monitoring system. The results maintain in the range of $0.2 \div 0.8 \%$ that fall within the safety range. The monitored gas concentrations before and after using the degasification technique are shown in Figures 4 and 5.

\section{Discussion and conclusions}

Meeting the demand of increasing production from Vinacomin, underground coal mines are being operated in greater depth and further sites. This makes mine ventilation and gas control more difficult and complex, especially for mines containing high risk of methane gas combustion and explosion (Le et al., 2021).

The measurements of gas concentration through the central monitoring system placed at the roadway of Seam 9TBII level -150/-80 m after degasification by drilling borehole prove the efficiency of the technique. The gas concentration reduced from the range of $1.3 \div 8 \%$ to the range of $0.2 \div 0.8 \%$. The degasification efficiency is $90 \div 95 \%$. The production can be then conducted continuously in safety.

The degasification technique by drilling long borehole is useful for the problem of gas control for not only Mao Khe Coal Company but also other coal companies in Vinacomin. However, because the drilling is carried out in coal seams, associated

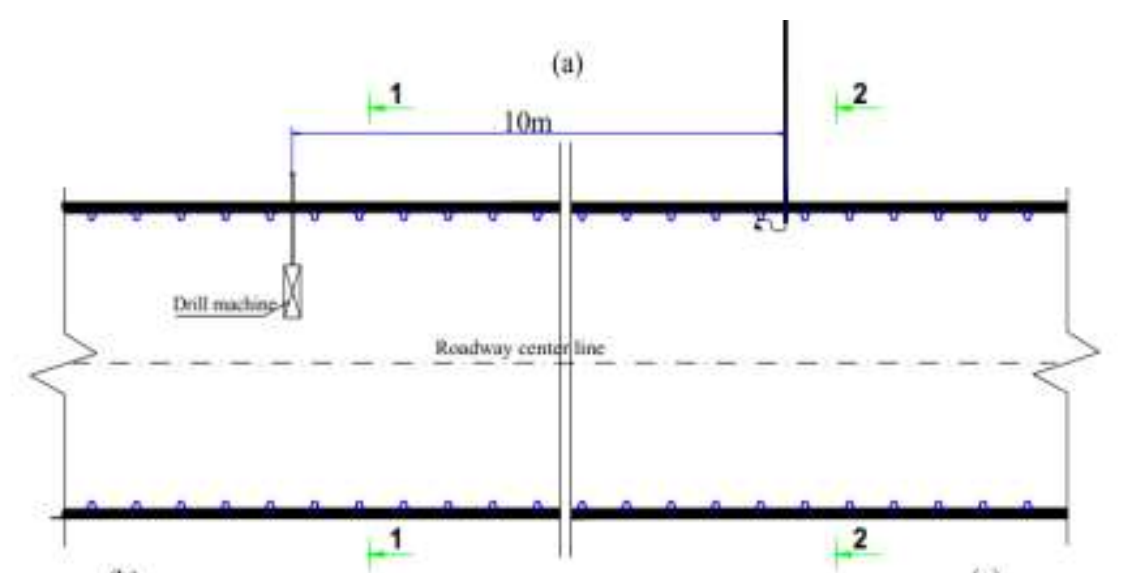

(b)

(c)
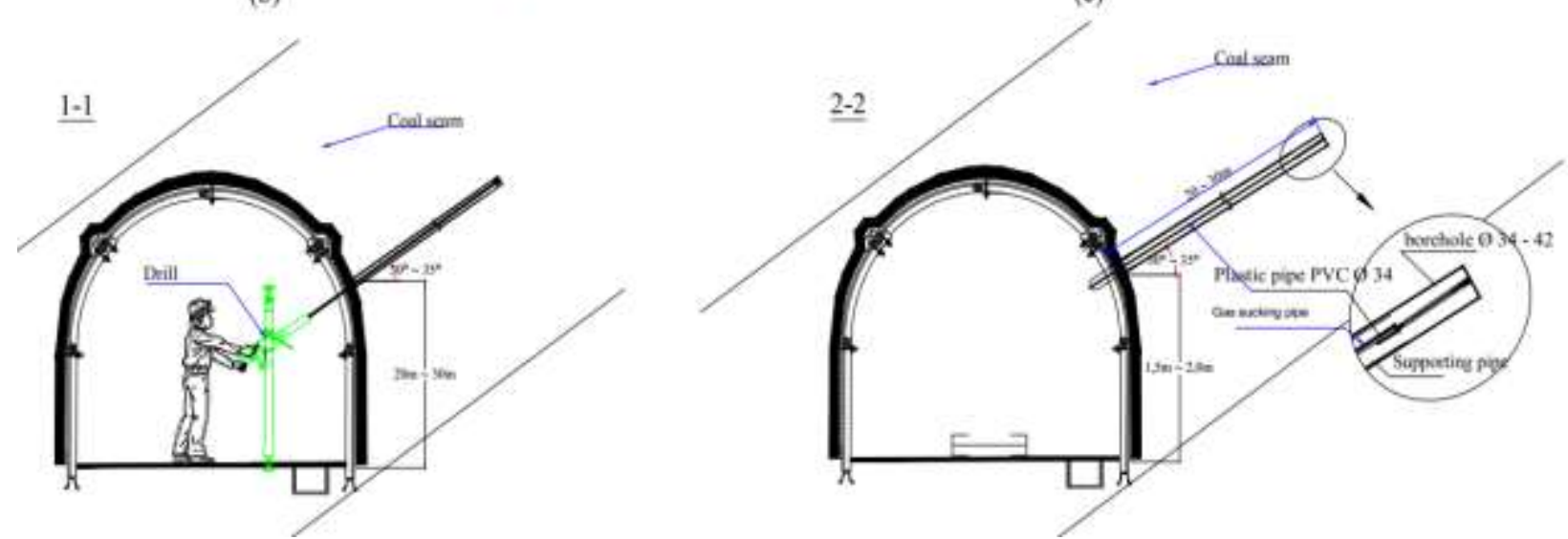

Figure 3. The degasification is implemented at the longwall's roadway by drilling a long borehole. 


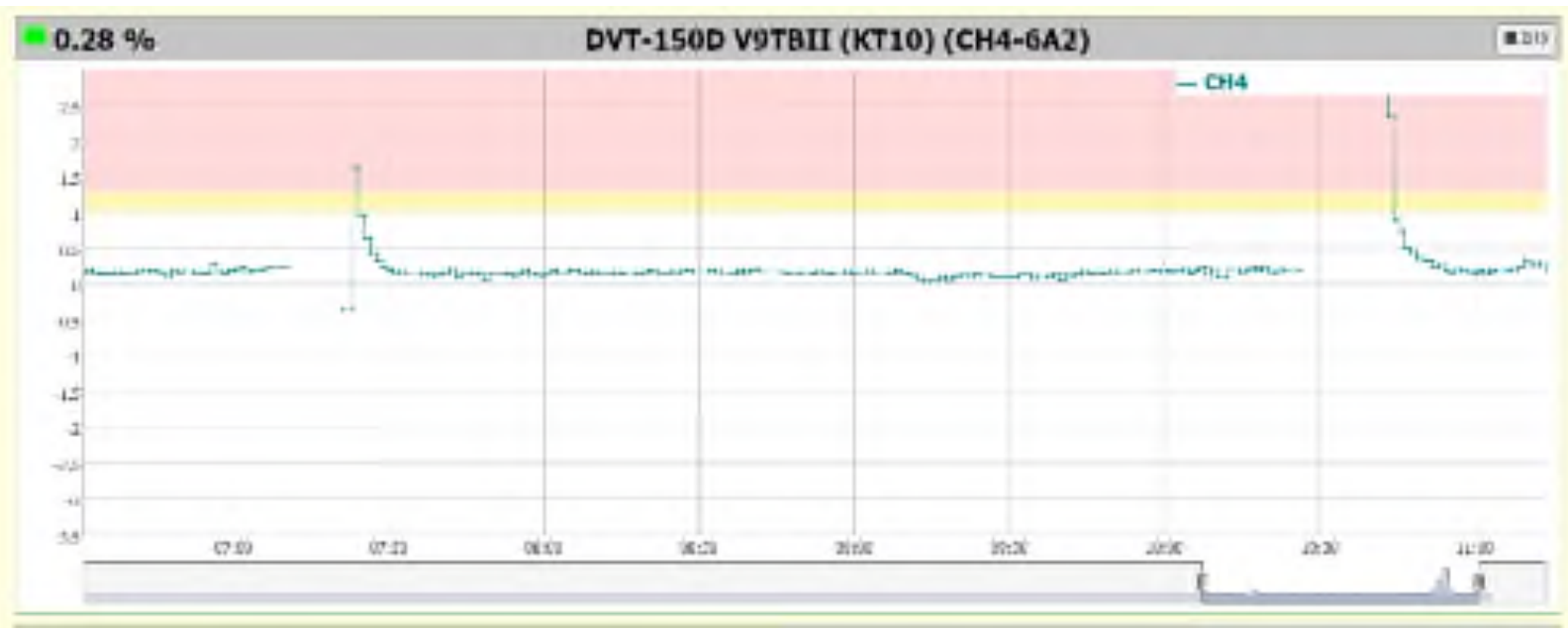

Figure 4. Methane concentration before drilling for degasification (Jun 2020).

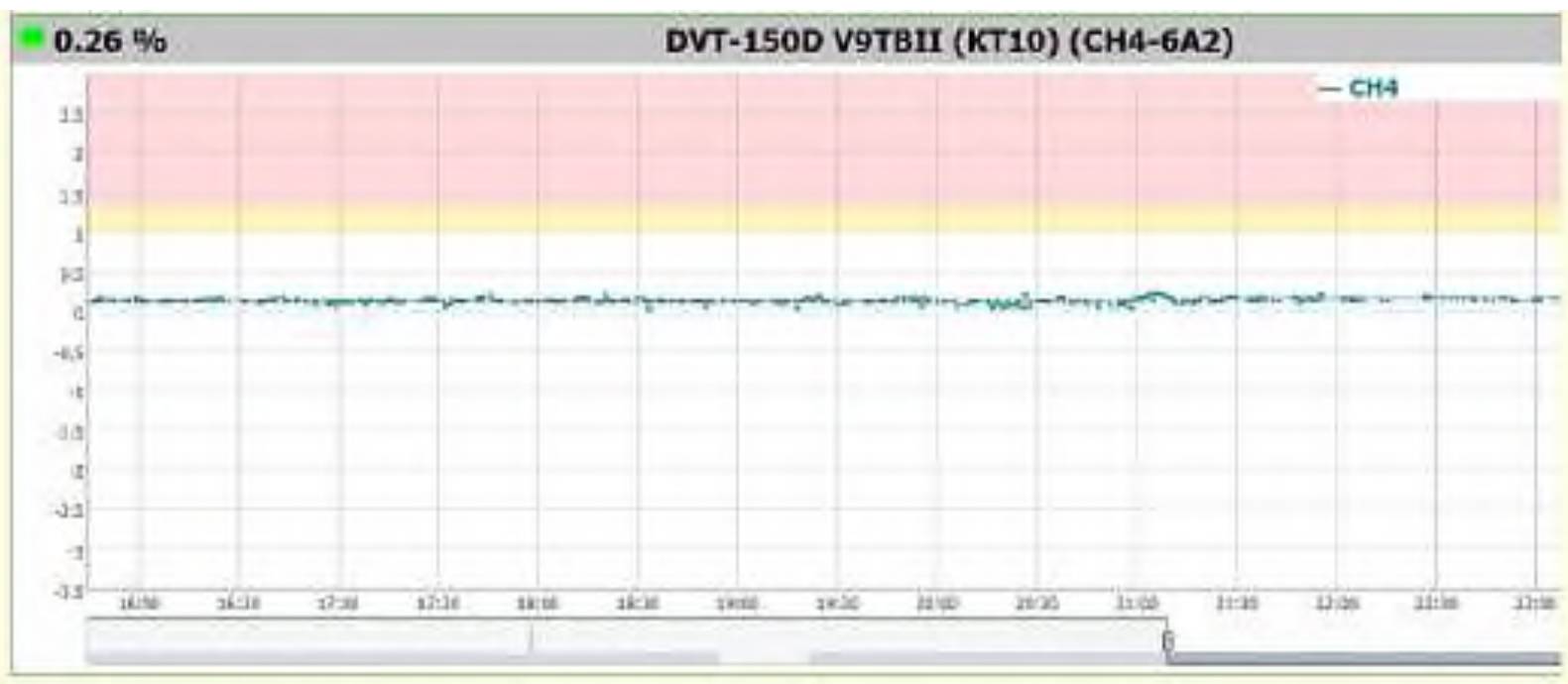

Figure 5. Methane concentration after drilling for degasification (September 2020).

geological conditions become significant. For example, in weak coal seam/roof strata, the maintenance of boreholes become difficult. A supplemental technique such as the Ejecter system can be used to improve the technique efficiency, which is a gas-attracted system made by Japanese technology using compressed air and has been successfully used in the Mao Khe coal mine.

Based on the application of the drilling technique for methane degasification at Mao Khe coal mine, the gas control in this mine and other underground mines of Vinacomin should be improved. The potential risk of methane gas combustion and explosion can effectively be minimized, ensuring safety at work and normal production as scheduled.

\section{Acknowledgments}

Mao Khe Coal Company is greatly acknowledged for approval of using field measurement data.

\section{Author contributions}

Duy Van Pham contributed to the idea, data acquisition and analysis. Dung Tien Le contributed to the analysis and writing. Son Anh Do contributed to collecting the data.

\section{References}

Center of Mining Safety - Vinacomin, (2020). Results of methane gas content and gas concentration in boreholes. Quang Ninh. 
Kundu, S., Zanganeh, J., \& Moghtaderi, B. (2016). A review on understanding explosions from methane-air mixture. Journal of Loss Prevention in the Process Industries, 40, 507-523. https://doi.org/10.1016/j.jlp.2016.02.004.

Le, T. T., Nguyen, M. P., Do, M. H., \& Hoang, Q. H. (2021). Study on classification of mines according to the level of danger of methane gas in underground coal mines in Quang Ninh region. Mining Technology Bulletin, (3), 43-51.

Mao Khe Coal Company, (2020). Initiative for last 6 months of the year 2020. Quang Ninh.

Thanhnien. (2014). Coal combustion in Quang Ninh may be caused by methane gas. Retrieved from https://thanhnien.vn/thoi-su/chay-lothan-o-quang-ninh-co-the-do-khi-metan459937.html.

Tran, X. H., Le, V. T., Dao, V. C., Nguyen, H. C., Le, T. P., Phan, Q. V., Phung, Q. H. (2019). Mine Ventilation Manual - Underground Traffics and Fans. Hanoi: Construction Publishing House.

Vietnam Government Portal. (2008). Methane explosion incident at Khe Cham coal mine, Quang Ninh. Retrieved from http://baochinhphu.vn/Tin-noi-bat/Su-cono-khi-metan-tai-mo-than-Khe-Cham-QuangNinh/19998.vgp.

Vietnam Ministry of Industry. (1999). DIRECTIVE: On strengthening technical safety management in coal mines and other minerals. Retrieved from
http://vbpl.vn/TW/Pages/vbpqtoanvan.aspx?ItemID=7256.

Vietnam Ministry of Industry and Trade. (2011). National technical regulations for safety in underground coal mining. Retrieved from http://vanban.chinhphu.vn/portal/page/port al/chinhphu/hethongvanban?class_id=1\&_pa ge=57\&mode=detail\&document_id=99378.

Vietnam Ministry of Industry and Trade. (20112020). Decisions on mine classification according to methane gas. Hanoi. Retrieved from https://thuvienphapluat.vn/vanban/tai-nguyen-moi-truong/quyet-dinh-983qd-bct-xep-loai-mo-theo-khi-metan135717.aspx? $\mathrm{v}=\mathrm{d}$.

Vietnam Ministry of Industry and Trade. (2021). Rank of mines according to methane gas for Vinacomin underground coal mines.

Vinacomin. (2016). Prevention \& response to methane explosion hazards: Things to "pocket". Retrieved from http://www.vinacomin.vn/tho-mo-ngaynay/phong-ung-pho-voi-hiem-hoa-chay-nokhi-me-tan-nhung-dieu-phai-bo-tui20161226105257382.htm.

VnExpress. (2002). Gas explosion in underground kills five people. Retrieved from https://vnexpress.net/no-khi-ham-lo-lam-5nguoi-chet-1962690.html.

VnExpress. (2006). Methane explosion, 8 workers died. Retrieved from https://vnexpress.net/no-khi-metan-8-congnhan-thiet-mang-2064612.html. 